\title{
The Center for Field Research
}

\section{Earthwatch Offers Grants for Labor-intensive Field Research}

Earthwatch, a private, non-profit-making organization, fosters scholarly research by offering capital, labor and greater visibility to the scientific community. The membership consists of individuals who want to learn more about scientific problems and to share in the challenge and excitement of solving them, thus providing a bridge between scholarly research and public education. The Center for Field Research receives, reviews and recommends research proposals for Earthwatch support. In recent years, about twenty percent of the research projects Earthwatch has supported have been in the marine sciences. In recognition of the growing importance of understanding marine biological, chemical and physical processes in order to best manage marine resources threatened by anthropogenic influences, Earthwatch is now committed to enhancing the level of its support to the marine sciences community.

Earthwatch funds are primarily derived from the contributions of participating volunteers selected from Earthwatch's 75,000 members world-wide; therefore, non-specialist volunteers must be integrated into the research design. Volunteers are enthusiastic, welleducated people who can be trained to perform a variety of tasks in a relatively short time.

Examples of the labor-intensive field research that Earthwatch is supporting in 1991-92 include:

- Biogeochemistry of Lake Naivasha, Kenya

- Eroded Sediment \& Nutrient Load in Tropical Estuaries of the Great Barrier Reef region, Australia

- Breeding Biology of the Leatherback Sea Turtle, St Croix, USVI

- Coral Reef Population Dynamics and Interactive Coral Reef Simulation Modelling, Netherlands Antilles

- Seagrass Biomass and Species Distribution: an Indicator of Oceanic Pollution, Bahamas

- Behavioral Ecology of Coral Reef Fishes, Belize

- Survey of Humpback \& Right Whale Breeding Grounds off Mozambique

- Population Density \& Ecology of Diamondback Terrapins, South Carolina

- Life History Studies of the Behavior of the Lemon Shark, Bahamas

- Fishes of the Canary Islands: Quantitative Habitat Study

- Population Biology \& Behavior of Atlantic Bottlenose Dolphins, Florida

- Microbial Ecology \& Biogeochemistry of Lake Baikal, USSR

- Coastal Geomorphic Response to Sea Level Rise, Caspian Sea, USSR

- Submarine Groundwater Discharge into the Gulf of Mexico

- Hydrology \& Hydrochemical Field Monitoring of Russian Northern Eutrophic Lakes

- Tubbataha Reef Marine Park Survey and Monitoring Project, Philippines

Preliminary proposals may be made by telephone or by a detailed letter to the Center for Field Research. Upon favorable review, full proposals will be invited for submission at least twelve months prior to the proposed start date of the project. Full proposals will be peer-reviewed. Proposals will be considered from scholars of any nationality, for research in any geographic region.

For further information contact: Andrew Hudson, Program Officer, Center for Field Research, 680 Mt Auburn St, Box 403, Watertown, MA 02272, USA; tel. (617) 926-8200; fax (617) 926-8532. 
Cover: The photograph on the outside of the cover was taken by David Nicholson at Pedney Beach, Cornwall.

Inside front cover: 'Busy Bee', a converted 60-foot steam yacht, owned by the MBA from 1896 until 1901, and used for teaching courses as well as research.

Inside back cover: SS 'Oithona', an 83-foot steam yacht, in Millbay docks during her conversion for research use. 'Oithona' was owned by the MBA from 1901 until 1921 and was used for the first regular investigations of the physics, chemistry and biology of the Western Channel and Approaches.

(C) 1992 The Marine Biological Association of the United Kingdom (Charity no. 226063)

CAMBRIDGE UNIVERSITY PRESS

THE PITT BUILDING, TRUMPINGTON STREET, CAMBRIDGE CB2 1RP

40 WEST 20TH STREET, NEW YORK, NY 10011-4211, USA

10 STAMFORD ROAD, OAKLEIGH, VICTORIA 3166, AUSTRALIAA

Printed in Great Britain by the University Press, Cambridge 


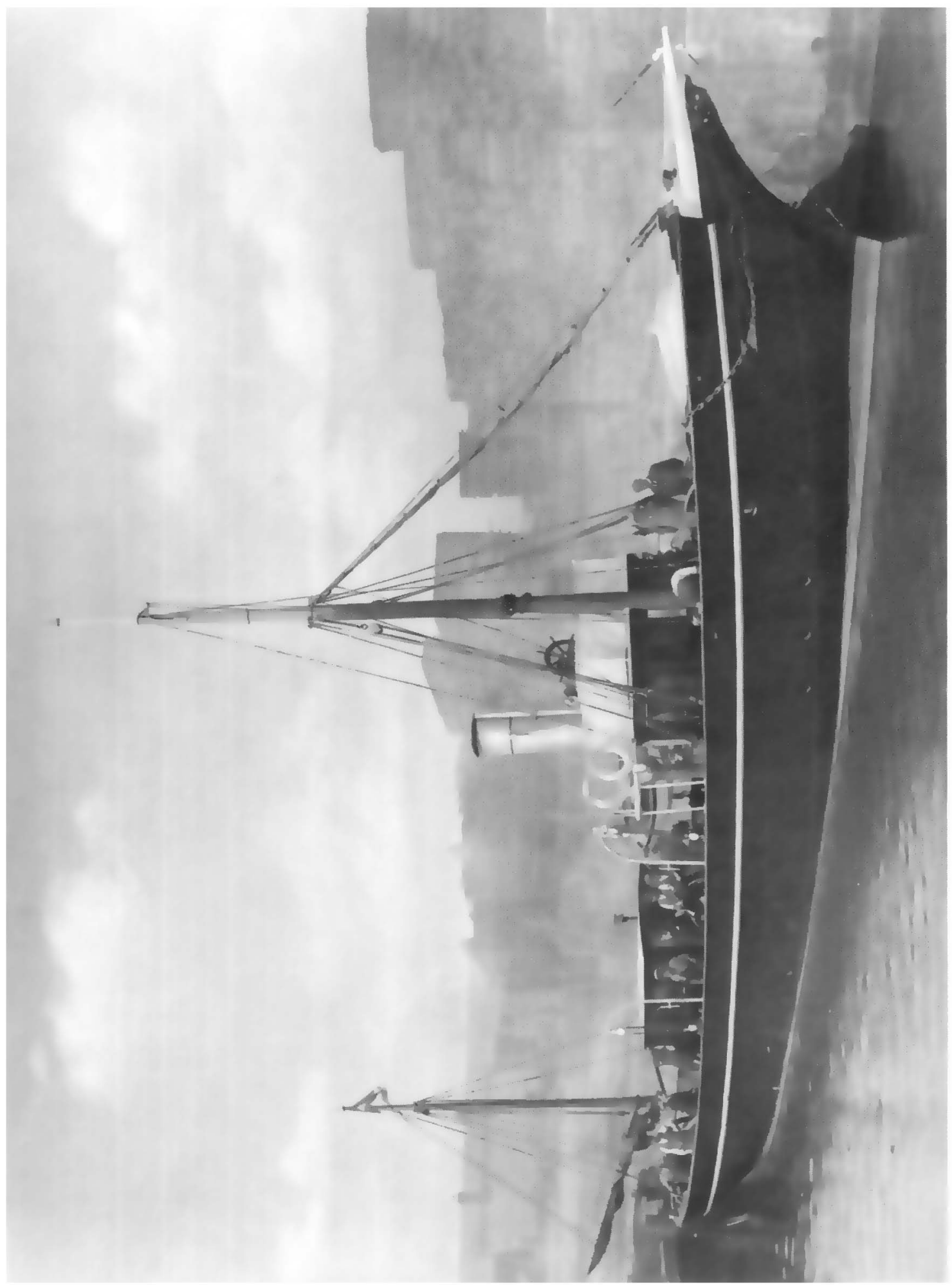




\section{JMBA}

JOURNAL OF THE MARINE BIOLOGICAL ASSOCIATION OF THE UNITED KINGDOM

VOLUME 72:2 MAY 1992

\section{CONTENTS}

PAGE

Natsukari, Y. \& Komine, N. Age and growth estimation of the European squid, Loligo vulgaris, based on statolith microstructure

Hatfield, E. M. C., Rodhouse, P. G. \& Barber, D. L. Production of soma and gonad in maturing female Illex argentinus (Mollusca: Cephalopoda)

Rodhouse, P. G. \& Hatfield, E. M. C. Production of soma and gonad in maturing male IIlex argentinus (Mollusca: Cephalopoda)

Lum-Kong, A., Pierce, G. J. \& Yau, C. Timing of spawning and recruitment in Loligo forbesi (Cephalopoda: Loliginidae) in Scottish waters

Wells, M. J., Wells, J. \& O'Dor, R. K. Life at low oxygen tensions: the behaviour and physiology of Nautilus pompilius and the biology of extinct forms

Bebianno, M. J., Langston, W. J. \& Simkiss, K. Metallothionein induction in Littorina littorea (Mollusca: Prosobranchia) on exposure to cadmium

Frolov, A. V. \& Pankov, S. L. The effect of starvation on the biochemical composition of the rotifer Brachionus plicatilis

Child, A. R. Biochemical polymorphism in bass, Dicentrarchus labrax, in the waters around the British Isles

Hateley, J. G., Grant, A., Taylor, S. M. \& Jones, N. V. Morphological and other evidence on the degree of genetic differentiation between populations of Nereis diversicolor

Gustafson, R. G. \& Lutz, R. A. Larval and early post-larval development of the protobranch bivalve Solemya velum (Mollusca: Bivalvia)

Williams, G. A. The effect of predation on the life histories of Littorina obtusata and Littorina mariae

Rice, A. L., Tyler, P. A. \& Paterson, G. J. L. The Pennatulid Kophobelemnon stelliferum (Cnidaria: Octocorallia) in the Porcupine Seabight (north-east Atlantic Ocean)

Harbison, G. R. Observations on the swimming and buoyancy of Cymbulia peroni (Gastropoda: Thecosomata) made from a submersible

Tyler, P. A., Young, C. M., Billett, D. S. M. \& Giles, L. A. Pairing behaviour, reproduction and diet in the deep-sea holothurian genus Paroriza (Holothurioidea: Synallactidae)

Robison, B. H. Bioluminescence in the benthopelagic holothurian Enypniastes eximia

Dales, R. P. Phagocyte interactions in echinoid and asteroid echinoderms

Pulsford, A. L., Ryan, K. P. \& Nott, J. A. Metals and melanomacrophages in flounder, Platichthys flesus, spleen and kidney

Short Communications:

Grahame, J., Mill, P. J., Double, M. \& Hull, S. L.

Auffret, M. \& Le Pennec, M.

Swaby, S. E., Potts, G. W. \& Wheeler, A. 